\title{
THE ISLAMIC TRADITION OF BUILDING WATER FOUNTAINS IN THE CRIMEA
}

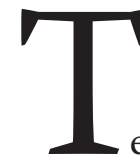

he cultural traditions of the Crimean Tatars, who have a long history stretching back over many centuries, have had a considerable influAt present, these traditions require the restoration and relearning of long forgotten technologies to reveal their peculiarities of artistic language and style, together with a renewal of folk traditions in modern art.

We can add the Islamic manner of building water fountains to such traditions. In all Muslim countries, especially in those of desert countries, water has had great significance, 'clean' running water being the most important.

The fountains were made to commemorate the memory of deceased relatives and fallen warriors, or simply for the good of a city, to preserve the memory of the important events in the life of those who built them. The arid Crimea, which has always been short of water, was no exception to these traditions. Around 120 fountains were built in Bakhchisaray alone, the water having been taken from 32 springs, a further hundred in Feodosia, and many more in Stariy Krim, Karasubazar, Simferopol and other cities and villages. Some of them were set up with the Khan's private money and that of other wealthy citizens of the city. In Bakhchisaray, for instance, the water fountains built near the main city gates, in the markets of the city and near some mosques, were financed by the Khan's own private money. They were also paid for from the rents of small shops, incomes from fruit gardens in the village of Suren, and from coaching inns in Bakhchisaray. ${ }^{1)}$

The water fountains, built and decorated in the Crimea, were put up near the walls of buildings, or sometimes installed separately. Such fountains

1) Archives SM ARC 
consisted of different types, depending on their use, for example: a cheshme is a small sources of water, an abdest fountain is used for ritual washing before prayer, fountain yards or pavilions are cosy water fountains inside buildings or gardens where you can have a rest, a sebil is a 'sacred' water fountain.

The cheshme type of fountain may be added to the list of traditional and most often used fountains. These were always the centre of social life in Crimean villages and were built, not only in the interior of the peninsular, but also along the roads on the south shore of the Crimea. Women coming to the fountains to take water discussed all kinds of news there; young fellows looked for a bride among the girls. "A small stone wall was simply rested on the steep mountain slope, sometimes it resembled a fireplace; a thin metal tube was thrust into it and water ran or dripped through it. Some fountains have Turkish inscriptions on the stone, which provide the name of a person, a benefactor, who built the fountain for the thirsty travellers passing by. Despite not being very eye-catching, nevertheless they proved very beneficial during a drought, which was the damnation of the Crimea, especially in hot weather. Some of the fountains supplied water to the whole vicinity". ${ }^{2}$

Cheshme water sources were built in the form of a vertical stele, about 1.5-2 meters high, with pointed arch niches. A small stone reservoir was usually built in front of it to accumulate water. Very often, a stone plate, with engraved Arab ornamental writing, bearing the name of the builder, was attached above it (Fig.1). The front wall of the reservoir was sometimes decorated in the form of a rosette with ornaments, that were either geometrical or in the shape of plants. The tradition of making such water fountains may be traced back to the late 19 th century.

The fountains preserved from the 15 th century show the influence of Muslim architecture. They were built by Armenians in Feodosia, at the foot of Mitridat Mountain, and were restored in the 16th century. The rectangular wall of the fountain has a niche in the form of a pointed arch and three carved rosettes above it. The middle rosette represents a solar sign; the side rosettes stand for the Star of David.

Two fountains of drinking water with arch niches, decorated in carved stone, were built in the 17th-18th centuries in the Ambassador's yard of Bakhchisaray palace. In the niches of one of the fountains, a tree resembling a palm tree was carved (Fig. 2). Water runs from its base into the stone reservoir, decorated with floral ornaments. The stone reservoir stands for the

2) Воропонов [Voroponov] (1992: 192). 
Earth, which had come to life and blossomed with rich plant life. The palm tree brought forth tasty fruits and water, as if illustrating the words of the Qur'an, that Allah had given water to people, created life on Earth, and grown dates there.

The Palace fountains of Bakhchisaray remind us of the fountains made by Turkish nobles, such as the 18th century fountains of Ustkunder III, in Ahmet Square, Istanbul. ${ }^{3)}$ Crimean Tatar fountains are more modest in decoration and smaller in form, however, and have their own meaning, as if they were the springs that brought forth life to all living creatures, and not just pompous constructions, eulogizing their builder.

Not far from Bulgakov's mosque, a fountain has survived in the village of Kokkoz and is still functioning. This was built from thick limestone in 1883, at the expense of the Bey of Bulgakov. The fountain has a small reservoir with a stele almost two metres in height, a pincerlike top and an arched niche. On the diorite construction board, placed on the upper part of the niche, the following words were transcribed in Russian and in Arab ornamental writing: "This fountain was installed by the court counsellor and Prince Ali Bey Bulgakov at his own expense and for the benefit of all”. The Ayvazovsky fountain in Phedosia was built in 1882, in the same style as the architecture of the Palace of Bakhchisaray, under the direction of I.K. Ayvazovsky himself (Fig. 3). In its dimensions, it resembles the Turkish fountain in Istanbul, dedicated to the memory of Ali Pasha Hekimoglu. ${ }^{4)}$ A square fountain is covered by a hipped roof with a large cornice figure. The roof is completed by five semi-cupolas (a tribute to Orthodoxy). The corner overhangs are decorated by plafond figures. It is lined by wooden laths at the bottom, as in the cornice of the palace of Bakhchisaray. It is painted and framed by a wide strap of carved wood on the perimeter. Stalactites decorate the bottom of the arch niche, whereas the top is decorated by wedge-shaped archivolts and ornaments. Marble columns have been made in the square cuts of the facade`s main corner. The other facades have niches completed in a semi-circular fashion. Marble rosettes have been set under the cornice, in hexahedral space. Water runs into the right-angled pools from the holes on four sides in the niches, at the level of the basement.

While building Yusupov's palace in the village of Kokkoz in the 19th century, the architect P. Krasnov used Crimean Tatar traditions in making

\footnotetext{
3) Barişta [Barishta] (1993, ill. 14, 73).

4) Barişta [Barishta] (1993, ill. 1).
} 
fountains. At the main entrance to the building, he made a very original wall fountain, 'the Blue Eye', designed in the form of a pointed niche. The niche is covered with majolica tiles of different shades of green, imitating a Crimean Tatar carpet - kilim (Fig. 4). The upper part of the arch is magnificently decorated with ornamental rectangular edging of blue tones. In the centre of a niche, there is a ceramic portrayal of a stylized blue eye, from which a stream of spring water runs into a reservoir, the water having been brought here from a mountain spring. The fountain has been completed in a modern style, and the idea of the blue eye comes from the legendary name of a village (in Crimean Tatar Kokkoz means 'blue eye'). A further fountain was built near the gates, made of cut off diorite blocks in the form of a three metre high stele. The fountain is covered with tiles, has a semi-circular niche, a water jet, a small reservoir and a landing on a level three steps high.

Characteristic traits of the fountain wall's decoration from the 15th-19th centuries include: carved rosettes with geometrical and floral ornaments made above a pointed arch niche, interlaced with ornaments in the form of plants, carved writing and epitaphs from the Qur'an, in the form of sulus inscriptions.

Fountains, supposedly for ablution (abdest), belong to the second group. As a rule, they were built near the mosques where Muslims usually prayed. They were mainly erected separately and had round, very often octahedral or hexahedral, forms of reservoir. As an example, we can take the fountain which was built to the left of Khan-Jamii's mosque in Bakhchisaray. A small pool (about 3 meters in diameter), covered with cupolas, was situated in the square yard, paved with tiles. Its bottom was covered with carved tiles of white marble, metal tubes were thrust through them and clean water poured into the round marble chute. Such fountains appeared in the Crimea at the time when the first mosques were built ${ }^{5)}$ and since then they have become their distinguishing feature.

Another form of fountain is the 'fountain yard' or 'pavilion'. These have been widely used inside the buildings and yards of the palaces and houses of the rich (Fig. 5). Comfortable water fountains create: "around the life-giving drops of water a peculiar shady atmosphere, protecting this small oasis from bright sun-rays and noisy shouting, when entering from the commotion of city streets into the fountain yard ... you cannot see anything at first in this cool shade. You will never get the whole image of it at once. Gradually, instant

5) Крикун [Krikun] (1998: 41). 
after instant, you'll see one detail after another. Everything here is made in a way to influence our sense perceptions, not only by internal images, but also by the musical movements of the water drops, the charm of the coolness itself, the picturesque quality of obscure darkness". $\left.{ }^{6}\right)$

A fashion for making fountain yards came from Constantinople, along with the first Crimean rulers (the Crimean Khans). Ceramic water tubes were found in Solhat, which were destined for the city fountains. The first mention of such fountains was found in the work of Evliya Chelebi, who had visited the Ashlama gardens in the palace of Ashlama Saray. Such a garden was found at the end of the 15th century in Salachik. The small yards and gardens of the palace of Bakhchisaray palace were decorated by very many such fountains. Up to the end of the 19th century, fountains were constructed in the city parks of Karasubazar, Ak-mechet, Gezlev and so on.

The tradition of making fountains inside buildings became widespread. They were placed in different summer houses, halls and sitting rooms. As an example, illustrating the 16th-18th centuries, we could take the fountains in summer house in (Alhambra) (Fig. 6), in the hall of the palace of Divan Bakhchisaray. In the 19th century, there were two fountains in the palace of Yusupov, one of which was a copy of 'the Fountain of Tears' in Bakhchisaray, and the other was placed in the foyer at the entrance to the park. All the fountains were made mainly from marble, with the use of ornamentation cut into stone, including borders with plant motifs. At the beginning of the 18th century, the bottom of the reservoirs were sometimes decorated with pictures of different fishes and birds, for example, near the garden of a pool or near the chute of a fountain in the Ambassador's yard. The central parts of the fountains were constructed in the form of, for example, a cypress or a blossoming bush.

By the 18th century, a new type of fountain had appeared in the art of the Crimean Tatars - the Sebil fountain. In the architecture of Arab countries, a sebil is a public water fountain, a source of clean water for drinking, free standing or placed against a wall, with one or several arch niches, or sometimes with bowls of water slowly running into a shell/basin. When translated from Arab it means a well (spring), intended for public use. It comes from the verb 'to make a donation for public use'. As a rule, such fountains were usually decorated with ornamental stone carving, coated in marble. Alternately, we might find ceramic mosaic calligraphy request-

6) Гинзбург [Ginsburg] (1992: 216). 
ing prayers for the benefactor, together with a quotation, saying or poetic couplet from the Qur'an. ${ }^{7)}$ Such fountains have been known in the Muslim world since the 14 th century.

The Crimean Tatar architects created quiet, cool fountains: "a babbling saga from the stone" (M. Ginsburg), with a stream of water slowly flowing down. The fountains were symbolic of the philosophy of the Qur'an and the theme of eternal existence. Then, in the 18th century, in the tradition of Osman Empire architecture, a new type of fountain appeared, 'the Golden fountain'. In the right-angled portal, a shallow arch niche is made, its top adorned with a carved stylized shell, ornamention in the form of plants and a belt of stalactites. The gilt of the ornamention and boldness of the writing proclaim the name of the fountain as: Manzub 'Golden' (Fig. 7).

In 1764, the Iranian artist-decorator made 'a fountain of tears wall' to commemorate the memory of the beautiful Dilyara Biketch. The artist used the language of symbolism to show his endless grief over her death in a small architectural form. The cascade fountain at the entrance to the durbe of Dilyara Biketch, and a wall fountain in the pool's patio, were built in the Sebil style.

In the 19th century, imitations such as further 'fountains of tears' were created in the palace of Empress Alexandra Fedorovna in Oreanda (architect A.I. Stackenschneider) and in the dinning-room of Yusupov's palace in the village of Kokkoz (architect N.P. Krasnov).

The main-size construction of a Sebil fountain was a vertical slab with a pointed niche; the bowls were then set in graded order. Water, overflowing from one bowl into the other, fell into a rectangular or oval reservoir, in front of the fountain's slab. The portal, as a rule, was decorated by carved plant ornamention in the form of creeping shoots or flowerpots. The motif of flowerpots was widely used in the 18th century in stone sculpture, as well as in metal artwork. Most likely, this tendency had come from Turkey, where it was widespread and can still be found; not only on the tiles of fountains and gravestones, but also on the side planes of mimbars of mosques built in the 18 th century. ${ }^{8)}$

Masters of the art of stone cutting used the symbolism of language widely on the small architectural form of a fountain. They sculpted lotus flowers with

7) Малиновская [Malinovskaya] (1993: 175-176).

8) Barişta [Barishta] (1998: Ills. 226, 227, 14, 73). 
five petals, numerals such as three and nine, bowls, formed stairs of zigzags, placed a snail on the bottom of the pool and so on.

A typical example of a cascading Sebil type of fountain, is the fountain in the patio of a pool in Bakhchsaray palace, consisting of marble slabs with 12 chutes, installed in the south wall. The fountain has both vertical and horizontal planes. The movement of water within them symbolizes birth, a stormy but short life, consisting of divisions and making generalizations, which may be contrasted with the eternal tranquillity and smooth surface of the pool, with a long canal in a horizontal line going towards it, lined with cypresses, symbols of the life beyond the grave. A snail is also there - the symbol of eternity and doubts. The association between fresh and salt water appears symbolic of the world itself. The main module of this whole work of art is the stream of water proportionate to that of a human being. The Crimea is a peninsular, which by God's will has been surrounded by seawater, with a scanty supply of fresh water. That is why wells and springs were regarded as being something akin to spiritual beings. Taking this into consideration, we can say that the Sebil fountain could be considered as being a model of the Crimea. ${ }^{9)}$

The epigraphy of the fountain contains information at two levels: the fountain as a source of life and purification, a sacral motif deriving from antiquity, reaching as far as the lower levels of cultural Islamic traditions; and the fountain as a book, understood only by those able to read. Its external, wholesome image is interpreted as if it were a page from the Qur'an, with an unvan (title, headline) and finished with alem (the half-moon on the top of the mosque used as a symbol of being above the world). The inscriptions on the fountains taken from the Qur'an, stress not only the integrity of the image of a book, but also convey information, as do inscriptions on buildings, weapons and everyday objects.

The writings on the fountains always end with the word selsebil, which has several meanings. In Muslim mythology, this bears the name of the main spring in paradise (Qur'an 78:18). In the architecture of Egypt, Syria, Palestine and Andalusia, starting from the 13-14th centuries, a system of cooling the interiors of buildings with water was developed, the main principle of which was slowly running a thin layer of a stream of water down a marble slab, at an angle of $15-30^{\circ}$. The water then ran into small decorative canals, evaporat-

9) Шейх-заде [Sheyh-Zade] (1995: 36). 
ing as it cooled the room. In the figurative meaning the word, selsebil denotes nectar, the drink of paradise.

Combining the sacred base of Qur'anic philosophy with poetic epitaph, made of marble and carved with décor, the Crimean Sebil type of fountain serve as memorials, reminding us of the fleeting joys of life, the inevitability of separation and the bliss of righteous souls in paradise. Sebils have a spiritual kinship with, and resemblance to, gravestones, on which was often carved something like a bowl on the upper part, which was always filled with rain water. The combination of planted greenery, water over the grave and the decoration of stone fountains, combined to bring them all together in their symbolic meaning.

In the 18-19th centuries, the carved décor of the fountains changed from the geometrical ornamention of the Seljuk and the Golden Horde period, slowly passing into the form of stylized plant ornamention, then taking the form of magnificent Baroque in the 18-19th centuries. By examining the aesthetics of buildings, we can trace: changes in the use of limestone (15-16th centuries), the later use of coloured and snow-white marble, the colouring of certain elements (17-18th centuries) and the obligatory presence (15-19th centuries) of poetic epitaphs and formulas from the Qur'an, in the form of calligraphic ornamentation. The writing on the fountains was sometimes very scanty and strict, merely providing information concerning the date of its construction and the name of the builder. At other times, however, it was possible to come across epitaphs, striking in their supreme poetical eloquence, representative of a very high style of Oriental poetry. Of course, the poetic pathos and magnificence of carved ornamental decorations, and even the size of the construction, might depend on the social position and desire of the customer, as well as the skill and individuality of the poet-engraver. The texts written on the fountains in the period of the Crimean Khans are more complicated than those written during the period of the Golden Horde. The creative work of hattats (master calligraphers), who, at the same time doing the work of cutting the stone, were also 'writers' and 'scribes', was reflected in their decoration of virtuoso calligraphy, made during the time of the Golden Horde, using classic sulus script, and later on with taalic (a written script), which was intertwined with plant ornamentation.

The skill of constructing fountains in the Crimea had a sacred basis, leaning on the fundamental theories of Islamic works of philosophy, with the conception of a syntheses of works of arts with surrounding nature. First of all, this is quite evident from religious perceptions of water as a source of 
life. Wide use of symbols allow those, who are devoted, to 'read' the theme of a construction as if it were a page from the Koran. Not only in the early periods, but also in the fountains of later periods, Muslim symbols intertwine with the pagan in an extraordinary fashion, as evidenced in some of the motifs, where a synthesis of Islamic and Christian art, Judaic symbolism and antic mythology, may be found. The difficult conditions from which the Crimean Tatar ethnic group had been formed, made for a community with a great variety of art, which, when combined with the art of a different neighbouring ethnos, as well as with the art of the people who lived on the shores of the Black Sea, led to the formation of the very rich and original decorative art of the Crimean Tatars.

\section{BIBLIOGRAPHY}

Архив СМ АРК = Council of Ministers of the Autonomous Republic of Crimea Archive (Archives SM ARC), Simferopol, f. 489, inv. 1д.650, v. 2-8.

Воропонов $(1992)=$ О. Воропонов, "Среди крымских татар" (Among the Crimea Tatars), Забвению не подлежит (из истории крымскотатарской государственности и Крыма), (Must not consign to oblivion (from the history of the Crimean Tatar statehood in the Crimea), Kazan, 1992: 192.

Barişta (1993) = H. Örcün Barişta, "İstanbul Çeşmeleri. Kabataş Hekimoğlu Ali Paşa Veydan Çeşmesi” (Istanbul Fountains. Fountain Stone Hekimoğlu Ali Pasha Vey), İstanbul 1993.

Крикун (1998) = Е.В. Крикун, “Памятники крымскотатарской архитектуры" (The monuments of Crimean Tatar architecture), Симферополь 1998: 41.

Гинзбург (1992) = М., Гинзбург, "Татарское искусство в Крыму" (Tatar art in the Crimea), Забвению не подлежит (из истории крымскотатарской государственности и Крымма), (Must not consign to oblivion, from the history of the Crimean Tatar State in the Crimea), Kazan 1992: 216.

Малиновская (1993) = A.N., Malinovskaya, "Семантическое поле бахчисарайского фонтана («слез») в контексте исламской традиции” (Semantic field of Bakhchisaray fountain ('of tears') in the context of Islamic tradition), История и археология юго-западного Крыма (History and archeology of the south-west of the Crimea), Симферополь, 1993: 175-176.

Barişta (1998) = H. Örcün Barişta, "Türk el sanatlari” (Turkish handicrafts), 2(1998): Ill. 226, Ill. 227.

Шейх-Заде (1995) = Ismet Sheyh-Zade, "Сакральные мотивы в крымском искусстве” (Sacral motives in Crimean Tatar Art), Qasevet, 1 (1995): 36. 


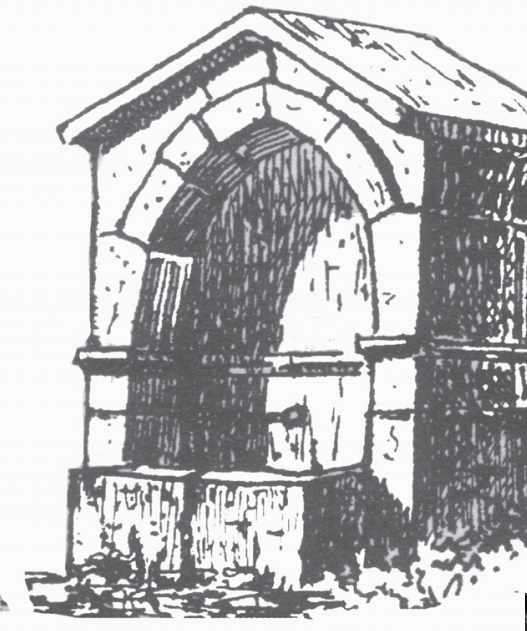

Fig. 1. Cheshme - the traditional and the most wide spread water fountain in the villages and along the roads in the Crimea

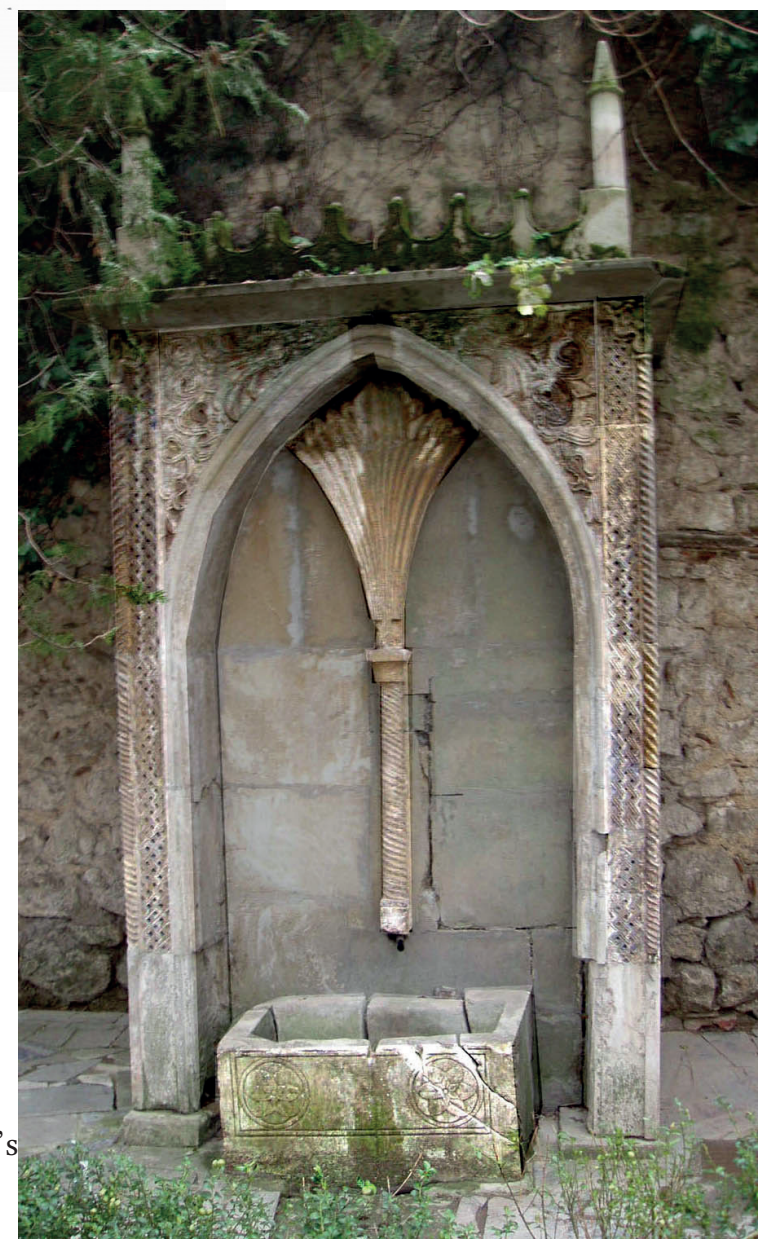

Fig. 2. A 17-18th century water fountain, built in the ambassador's yard in Bakhchisaray 


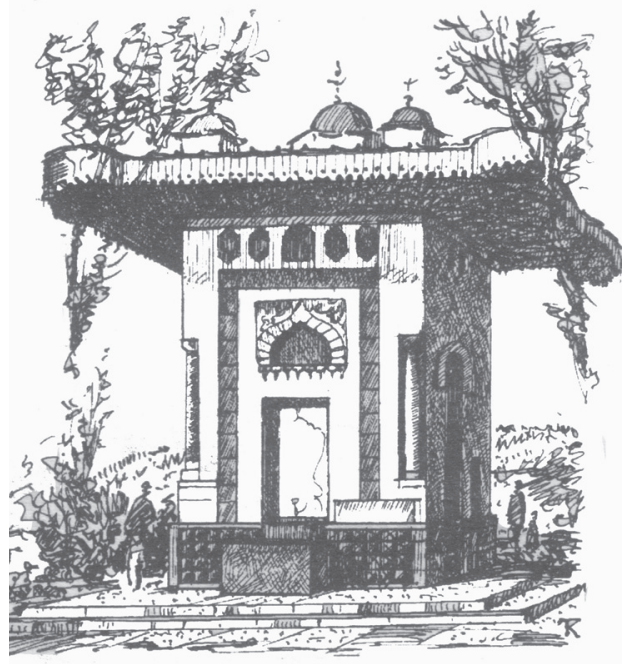

Fig. 3. The Ayvazovsky fountain (1888). Theodosiya

Fig. 4. The 'Kokkoz' fountain in the village of Kokkoz. Architect - Krasnov N.P.

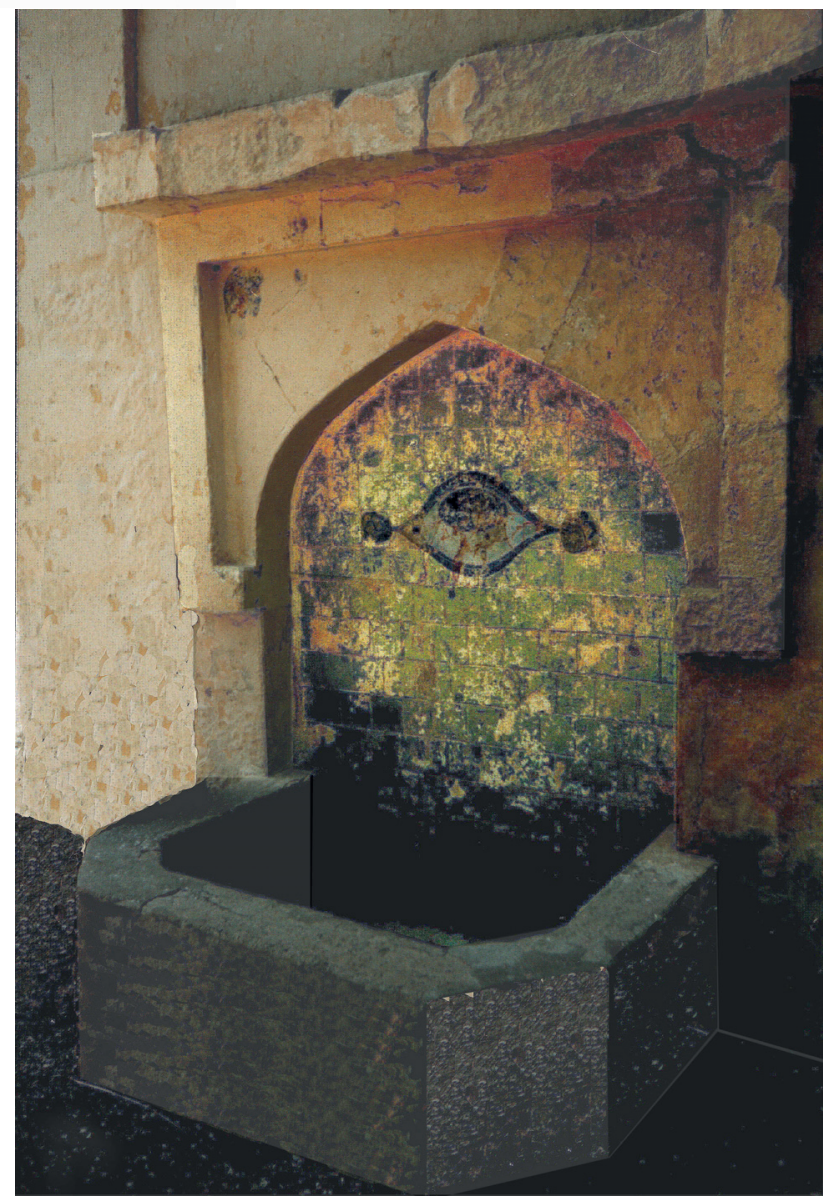



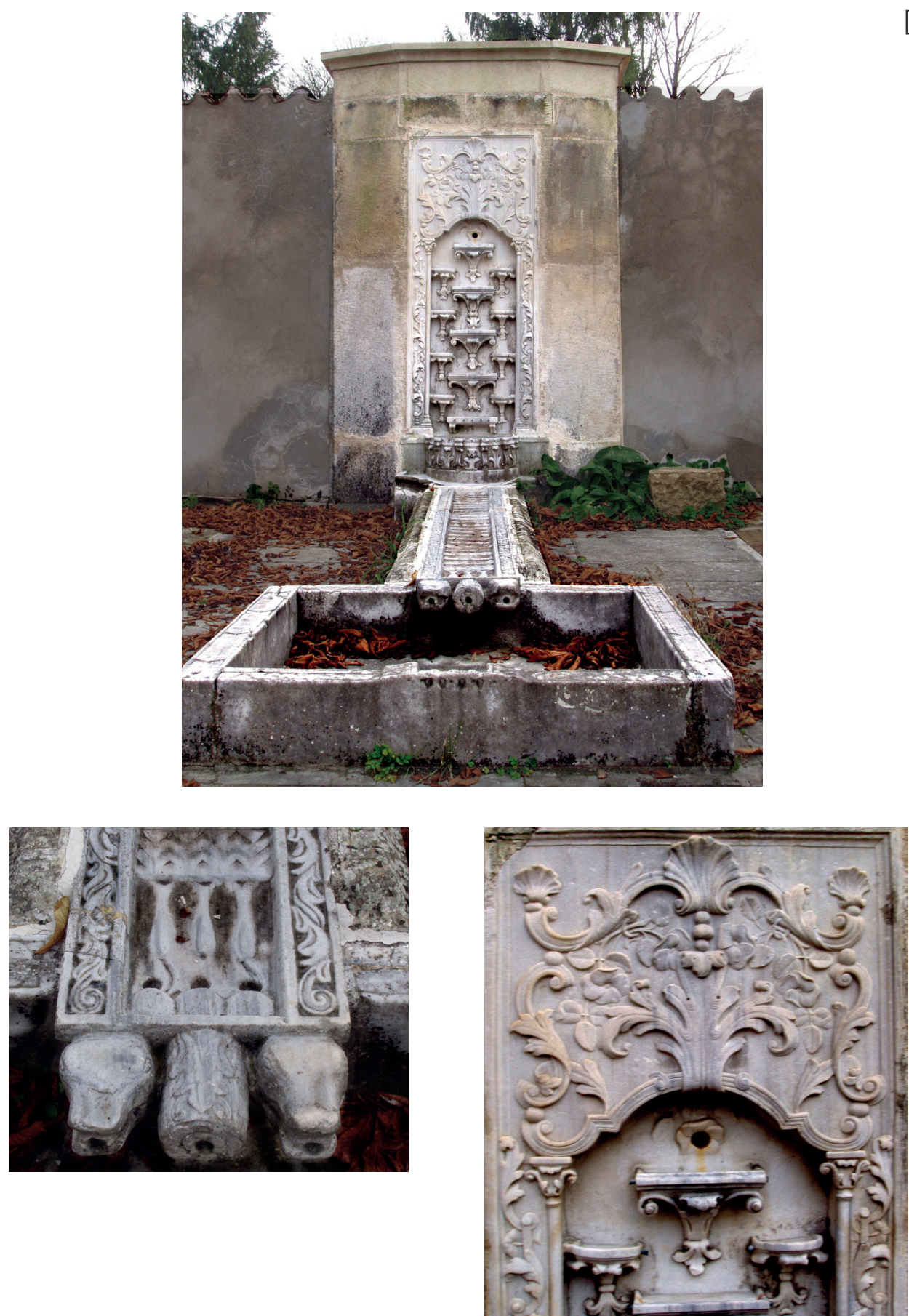

Fig. 5. The fountain yard in Bakhchisaray palace: a fountain with two pools 


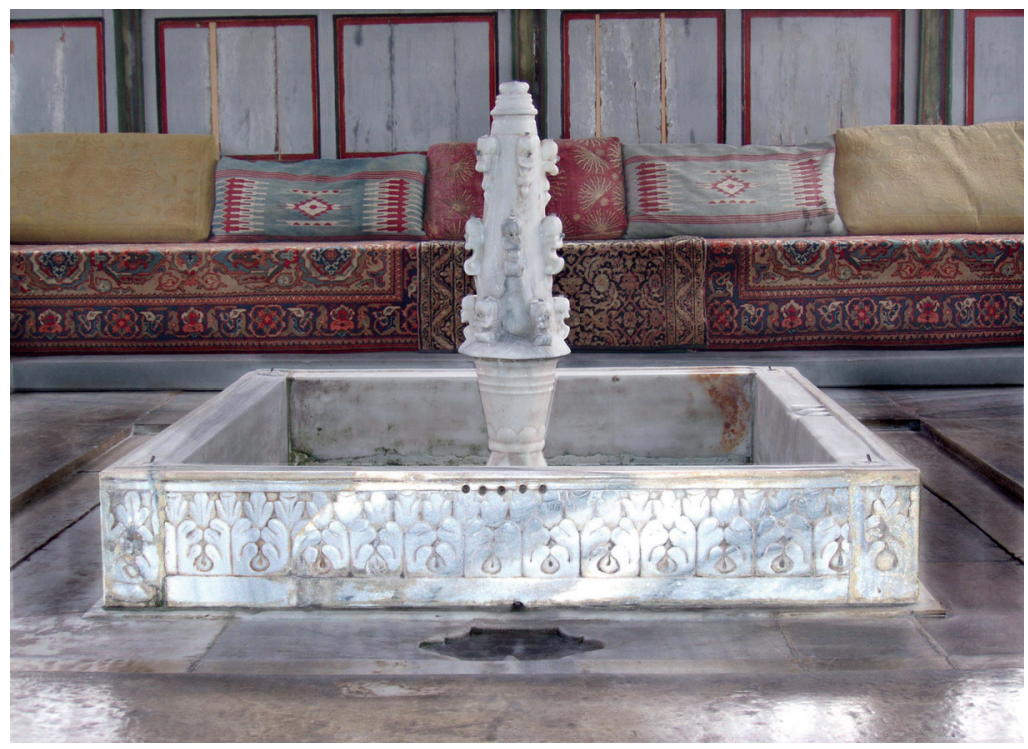

Fig. 6. A 17-18th century fountain in the summer house (Alhambra) of the palace of Bakhchisaray

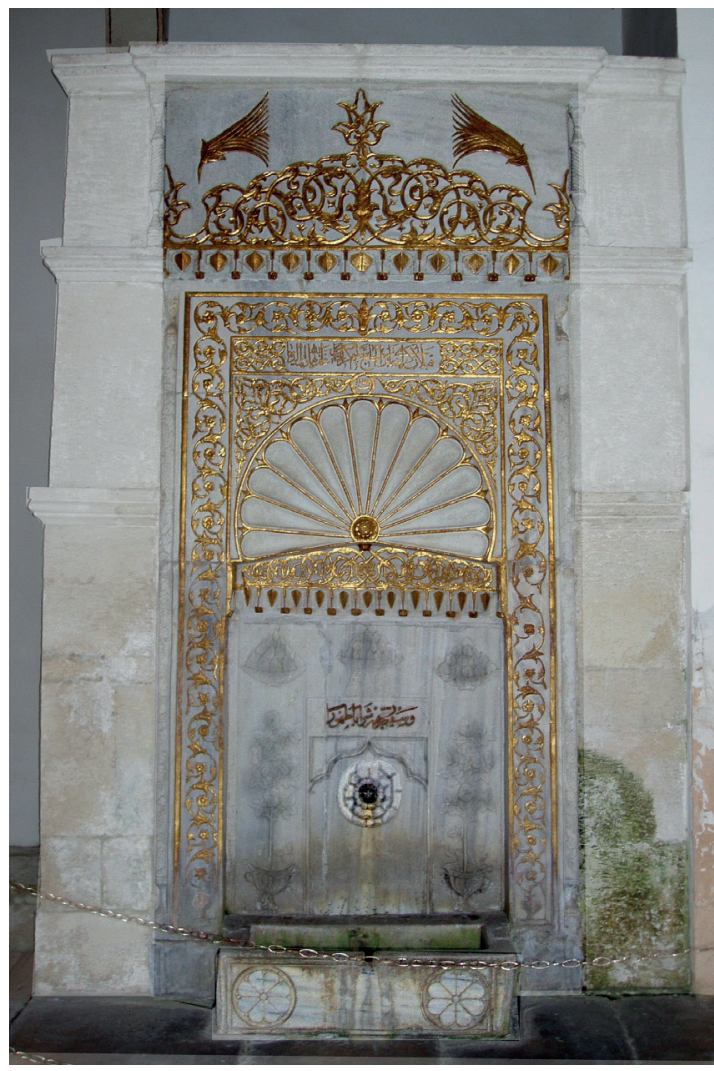

Fig. 7. 'The Golden fountain' - Manzub. 18th century. The palace of Bakhchisaray 